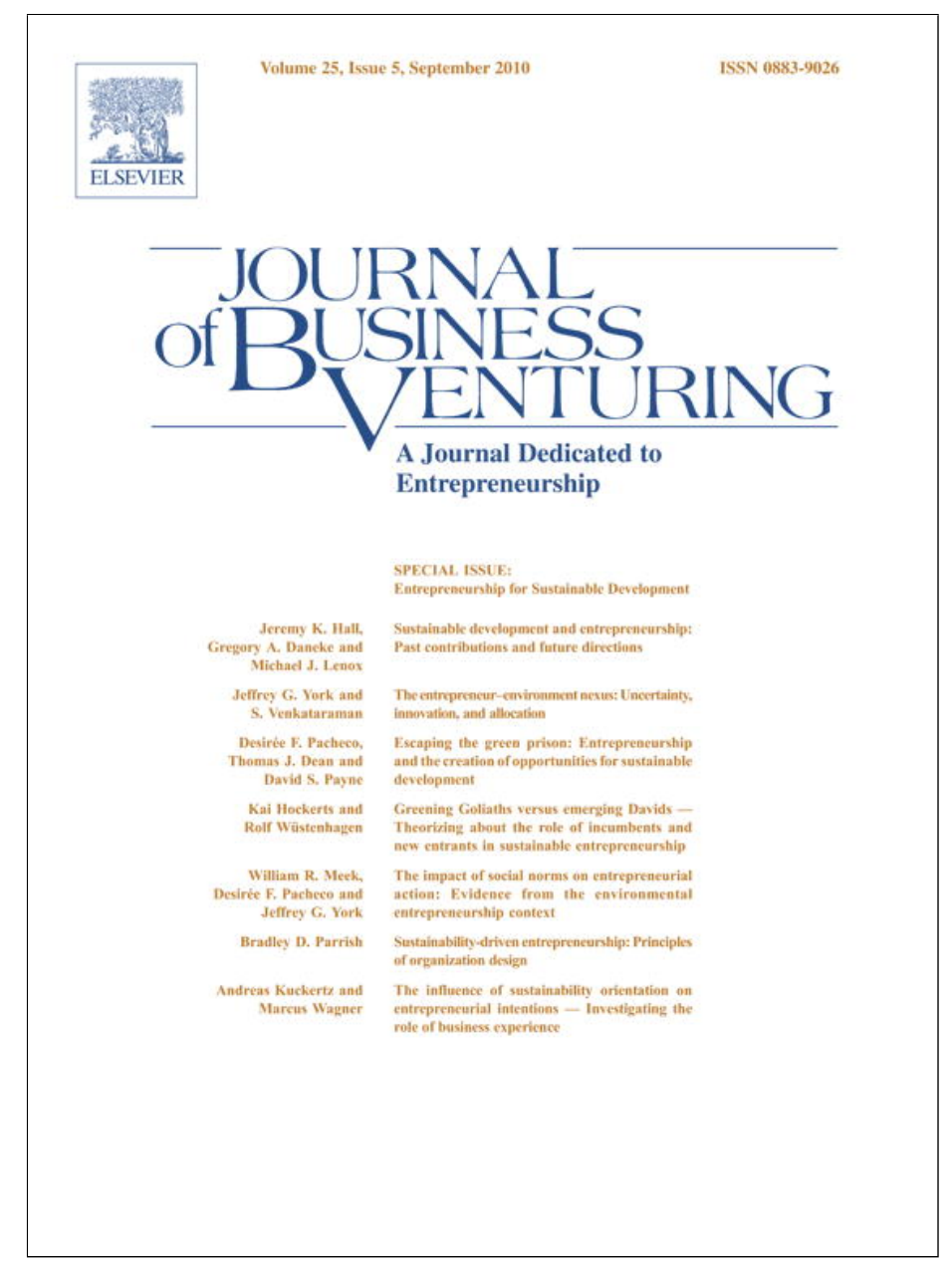

This article appeared in a journal published by Elsevier. The attached copy is furnished to the author for internal non-commercial research and education use, including for instruction at the authors institution and sharing with colleagues.

Other uses, including reproduction and distribution, or selling or licensing copies, or posting to personal, institutional or third party websites are prohibited.

In most cases authors are permitted to post their version of the article (e.g. in Word or Tex form) to their personal website or institutional repository. Authors requiring further information regarding Elsevier's archiving and manuscript policies are encouraged to visit:

http://www.elsevier.com/copyright 


\title{
Greening Goliaths versus emerging Davids - Theorizing about the role of incumbents and new entrants in sustainable entrepreneurship
}

\author{
Kai Hockerts ${ }^{\mathrm{a}, *}$, Rolf Wüstenhagen ${ }^{\mathrm{b}}$ \\ a Copenhagen Business School, Centre for Corporate Social Responsibility (cbsCSR), Denmark \\ ${ }^{\mathrm{b}}$ University St. Gallen, Institute for Economy and the Environment (IWOe-HSG), Switzerland
}

\section{A R T I C L E I N F O}

\section{Keywords:}

Entrepreneurship

Corporate sustainability

Incumbents

Start-ups

\begin{abstract}
A B S T R A C T
This paper proposes a model of how incumbents and new entrants engage in sustainable entrepreneurship. We suggest that in the early stages of an industry's sustainability transformation, new entrants ('Emerging Davids') are more likely than incumbents to pursue sustainability-related opportunities. Incumbents react to the activities of new entrants by engaging in corporate sustainable entrepreneurship activities. While these 'Greening Goliaths' are often less ambitious in their environmental and social goals, they may have a broader reach due to their established market presence. This paper analyses the interplay between 'Greening Goliaths' and 'Emerging Davids' and theorizes about how it is their compounded impact that promotes the sustainable transformation of industries.
\end{abstract}

(c) 2009 Published by Elsevier Inc.

\section{Executive summary}

Global climate change and the accelerating depletion of natural resources are just two of several phenomena indicating that the world is not well aligned with the concept of sustainable development (Brundtland Commission, 1987). The severity of global sustainability challenges leads to an increasing awareness that incremental solutions will not be enough to maintain critical levels of natural and social capital (Russo, 2003), and hence there is an increased interest in sustainable entrepreneurship as a phenomenon and a research topic (Cohen and Winn, 2007; Dean and McMullen, 2007). Sustainable entrepreneurship research has evolved from two separate research streams on environmental and social entrepreneurship (Zahra et al., 2009), and has traditionally focused on small firms, sometimes down to the level of the individual entrepreneur. This inclination to focus on sustainability-related start-ups and their founders is perhaps an adequate counter-trend towards the inherent large-firm focus in existing corporate sustainability literature. However, while their actions are important, there are arguably a number of limitations to the impact that small firms can have on the sustainable transformation of industries. Sustainability-related entrepreneurial initiatives within large firms, on the other hand, are also not free from challenges. By referring to the processes of "Emerging Davids" and "Greening Goliaths", this paper presents a conceptual framework that discusses the relative contributions of small and large firms to the transformation of industries towards sustainable development. In addition to discussing the relative strengths and weaknesses of "Davids" and "Goliaths", we also develop a model of how they interact over time, thereby showing that it is their compound impact that leads an industry towards sustainability. We argue that in the early stages of an industry's transformation towards sustainability, it is typically small firms and new entrants that stimulate disruptive sustainability innovation. Attracted by the early market success of Davids, Pioneer Goliaths follow up with corporate sustainability entrepreneurship initiatives of their own. Thanks to their larger scope, these initiatives take the sustainable transformation

\footnotetext{
* Corresponding author.

E-mail addresses: kho.ikl@cbs.dk (K. Hockerts), rolf.wuestenhagen@unisg.ch (R. Wüstenhagen).
} 
of an industry to the next level. Because of their complementary skills and challenges with regard to sustainable entrepreneurship, a co-evolution of "Emerging Davids" and "Greening Goliaths" is more likely to result in sustainability than either of the two alone.

Our conceptual framework and findings have important implications for research and practice, perhaps more so than ever in the light of the current confluence of the financial and climate crises. Just consider the example of the car industry: As demand for gas-guzzling vehicles has faltered and large incumbent car manufacturers are struggling to survive, it has become clear that there is a dire need for sustainable entrepreneurship. But where should policy makers focus their efforts in order to facilitate a sustainable transformation of the car industry - pushing towards "Greening Goliaths", hence funding innovation within Detroit's incumbent firms? Or should they rather focus on supporting "Emerging Davids", as some of Silicon Valley's high-profile entrepreneurs such as Shai Agassi or Elon Musk, founder of Tesla Motors, suggest (Waters, 2008)? Rather than exclusively listening to the voice of incumbents (which is arguably a popular approach in politics) or putting all eggs in the basket of start-ups, policy makers would be well advised to consider the specific strengths and weaknesses of both options and to pursue a portfolio that provides simultaneous incentives for Greening Goliaths and Emerging Davids. As for entrepreneurs in small and large firms, this paper helps them come to a realistic assessment of what their contribution towards the sustainable transformation of an industry can be, and where they should consider partnering with complementary counterparts. Finally, for researchers of sustainable entrepreneurship, we outline a number of specific suggestions for future research at the interface of Goliaths and Davids.

\section{Introduction}

Businesses in many industries are increasingly confronted with environmental and social challenges. Rather than just focusing on short-term profits, stakeholders expect firms to meet a triple-bottom line of economic, environmental and social value creation (Elkington, 1997). The increasing importance of sustainable development creates new risks, but also new opportunities for businesses. Reaping these opportunities requires firms to come up with innovative solutions for tomorrow's markets (Hart and Milstein, 2003). There seems to be an increasing awareness that there is a business case for sustainable entrepreneurial initiatives, and achieving "green growth" (Ki-moon and Gore, 2009) is a popular theme in the political debate. But how does green growth come about? What does it take for sustainable entrepreneurs to blossom? And particularly, is sustainable entrepreneurship something that happens in large firms or small firms?

The aim of this paper is to provide a conceptual contribution to clarify the role of two different visions of sustainable entrepreneurship, which we refer to as 'Greening Goliaths' and 'Emerging Davids'. Our objective is to discuss the relative strengths and challenges of large and small firms in embarking on sustainable entrepreneurship, and to develop an evolutionary model of how their compounded impact promotes the sustainable transformation of industries.

The paper proceeds as follows. The following section (Section 3) clarifies the terminology used in this paper and briefly introduces key concepts. Section 4 provides a review of existing literature on sustainable entrepreneurship, as well as the two related concepts of environmental and social entrepreneurship. It ends with a review of studies at the intersection of firm size and (sustainable) innovation. Section 5 then includes the key conceptual proposition, and explores the interplay between 'Davids' and 'Goliaths'. Section 6 concludes the paper, provides suggestions for further research and highlights implications for entrepreneurs and policy makers.

\section{Terminology}

The notion of sustainable entrepreneurship is rather recent and its definition is still emerging. Dean and McMullen's focus on market failures in their definition of sustainable entrepreneurship as "the process of discovering, evaluating, and exploiting economic opportunities that are present in market failures which detract from sustainability, including those that are environmentally relevant" (Dean and McMullen, 2007). Cohen and Winn also stress the discovery of opportunity as essential when they posit that sustainable entrepreneurship research examines "how opportunities to bring into existence future goods and services are discovered, created, and exploited, by whom, and with what economic, psychological, social, and environmental consequences" (Cohen and Winn, 2007: 35).

This paper explicitly draws on the Schumpeterian (1962 [1934]) notion of entrepreneurship as an innovative process of creating market disequilibria (Eckhard and Shane, 2003; Shane and Venkataraman, 2000) which in turn lead to imitation. We thus define sustainable entrepreneurship as the discovery and exploitation of economic opportunities through the generation of market disequilibria that initiate the transformation of a sector towards an environmentally and socially more sustainable state.

By linking sustainable entrepreneurship to the transformation of an industry towards sustainable development, we respond to Cohen and Winn's call for going beyond research on "corporate 'greening' initiatives and their impact on firm performance, [which] (...) is focused on incremental innovation (...)" (Cohen and Winn, 2007: 47). Sustainable entrepreneurship can be linked to both product and process innovation. In industries where key environmental and social aspects occur in the use phase of the product life cycle, such as for example cars or heating systems, sustainable entrepreneurship will more likely be associated with product innovation. In other industries, process innovation may be equally important.

Since sustainable entrepreneurial opportunities are typically linked to market failures or externalities, exploiting these opportunities involves both market- and non-market strategies (Baron, 1995; Hillman and Hitt, 1999). We define non-market strategies as the set of activities that firms use to influence social, environmental and political stakeholders. 
Table 1

Characteristics of Davids and Goliaths.

\begin{tabular}{lll}
\hline Criteria & Davids & Goliaths \\
\hline Age & Rather new & Old, incumbent \\
Size & Small & Large \\
Objective function & Social and/or environmental objectives at least as & Economic objectives dominating, \\
& important as economic objectives & social/environmental objectives complementary \\
\hline
\end{tabular}

In this paper, we are suggesting that there are two different types of organizations that engage in sustainable entrepreneurship, namely "Davids" and "Goliaths" (see Table 1). While inherently metaphorical, these terms shall be defined as precisely as possible in the current chapter. By Davids, we refer to small firms that tend to be recently founded and have a relatively small market share. In the context of sustainability, we are particularly interested in those among the larger population of small firms that explicitly aim at providing not just economic value, but also social and environmental value. By Goliaths, we refer to large incumbent firms who tend to be older and have a relatively high market share.

Both the emergence of Davids as well as a process of "Greening Goliaths" can result in a transformation of an industry towards sustainability. We use the term "greening" in its colloquial sense. In public discourse "greening" is often used as a synonym for sustainable development. We do, however, stress that sustainable development should not be restricted to just environmental protection but needs to include the social and economic dimension as well. Fig. 1 visualizes the key concepts that we are using in this paper and how they relate.

Both Davids and Goliaths engage in sustainable entrepreneurship, but not all activities by Davids or Goliaths to improve environmental or social performance can be characterized as sustainable entrepreneurship. In line with our definition of sustainable entrepreneurship provided above, we use the term sustainable entrepreneurship to describe activities by small or large firms that represent disruptive, rather than incremental innovation. Goliaths routinely engage in incremental environmental or social process innovation, e.g. through the introduction of sustainability management systems, eco-efficiency or corporate social responsibility initiatives (Schaltegger, 2002). In our terminology, those activities would not qualify for the term (corporate)

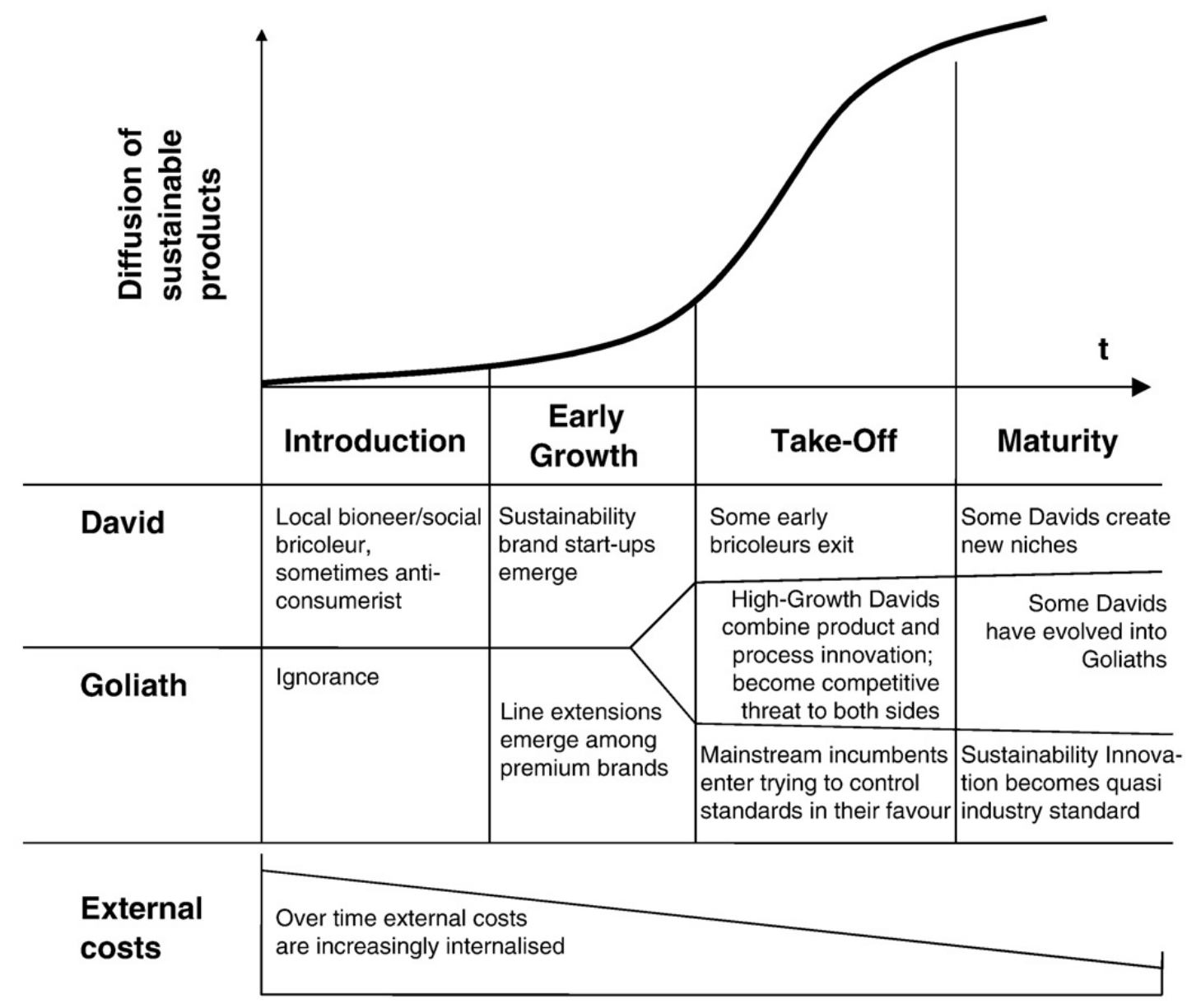

Fig. 1. Emerging Davids and Greening Goliaths. Source: adapted from (Wüstenhagen, 1998). 
Table 2

Delineation of sustainable entrepreneurship.

\begin{tabular}{lll}
\hline & Davids & Goliaths \\
\hline Disruptive innovation & Sustainable entrepreneurship & $\begin{array}{l}\text { Sustainable corporate } \\
\text { entrepreneurship }\end{array}$ \\
Incremental innovation & Bioneers, social bricoleurs & $\begin{array}{l}\text { Sustainability management } \\
\text { systems, CSR, eco-efficiency }\end{array}$ \\
\hline
\end{tabular}

sustainable entrepreneurship. Equally, Davids who are active in a high-end environmental or social niche, but with no intention to broaden their impact on a wider market would be categorized as incrementally innovative and hence not sustainable entrepreneurs. These "bioneers" (Schaltegger, 2002) or "social bricoleurs" (Zahra et al., 2009) often come from the voluntary sector and sometimes tend to be opposed to consumerism and growth. They worry that mainstreaming requires them to abandon their ideals (Table 2).

\section{Literature review}

\subsection{Sustainable development and entrepreneurship}

The term sustainable development ties together concern for the carrying capacity of natural systems with the social challenges facing humanity (Brundtland Commission, 1987; Keating, 1993). As early as the 1970s, sustainability was employed to describe an economy "in equilibrium with basic ecological support systems" (Stivers, 1976: 187). Traditionally ecologists have pointed to the "limits of growth" (Meadows et al., 1971; Meadows, 1977; Meadows et al., 1991) and demanded a "steady state economy" (Daly, 1973,1991 ) in order to address environmental concerns. The sustainable development debate is based on the assumption that societies need to manage three types of capital (economic, social, and natural), which may be non-substitutable and whose consumption might be irreversible (Dyllick and Hockerts, 2002).

Daly (1991) stresses the fact that economic capital cannot necessarily substitute natural capital. Forests, for example, provide raw material for paper (which is easily substitutable), but they also maintain biodiversity and absorb $\mathrm{CO}_{2}$ (Siebenhüner et al., 2005). Another problem of natural and social capital deterioration lies in their partial irreversibility. Moreover, the depletion of natural and social capital may have non-linear consequences. A lake can, for example, absorb nutrients while increasing its productivity, only to break down all of a sudden once a certain level of algae is reached.

If the degradation of natural and social capital has such important consequence the question arises why action is not taken more systematically to alleviate it. Cohen and Winn (2007) point to four types of market failure as possible explanations: Firstly, while the benefits of natural or social capital depletion are privatized the costs are often externalized. Many times natural capital is also undervalued by society since we are not fully aware of the real cost caused. Information asymmetry is a third reason identified to cause natural and social capital depletion. Cohen and Winn close with the realization that contrary to economic theory many firms are not perfect optimizers.

As awareness of sustainable development grows in society, the market failures discussed by Cohen and Winn are likely to diminish. For example, they expect that society will increasingly realize the value of natural and social resources boosting their economic value. As a result firms will have to internalize costs that formerly have been borne by society. This change is called the sustainability transformation of an industry (Dyllick, 1999; Dyllick et al., 1997).

\subsection{From social and environmental entrepreneurship to sustainable entrepreneurship}

While social and environmental aspects of sustainable development are inextricably linked, a large part of the academic literature on sustainability entrepreneurship deals with either one or the other. A first group of authors put environmental innovation at the heart of their work. These literature contributions have coalesced around the theme of eco-innovation, which more recently has spawned the subdiscipline of clean-technology venturing (Boehnke and Wüstenhagen, 2007; Hart and Milstein, 1999; Parker and O'Rourke, 2006). A second line of publications deals with innovations aiming at social improvements (e.g. health, education, community development). Here the term social innovation can refer to product or process innovations with a social purpose. A subgroup of these types of innovations concerns "Base of the Pyramid" (Prahalad and Hammond, 2002; Prahalad and Hart, 1999) thinking. Social innovation is also used to refer the process of starting and improving social enterprises.

The notion that sustainable development drives disruptive innovation (Christensen 1997) has come quite naturally to the sustainability debate (Cohen and Winn, 2007; Hockerts, 1999, 2003; Wüstenhagen et al., 2008). Sustainable entrepreneurship has been proposed as a "breakthrough discipline for innovation" (Fussler, 1996), as a "source of creative destruction" (Hart and Milstein, 1999: 23), as well as the beginning of the "next industrial revolution" (Braungart and McDonough, 1998: 82; Lovins et al., 1999: 1; Senge and Carstedt, 2001: 24). From this has emerged a large number of publications advancing tools for furthering the creation of new markets through environmental innovation (Fussler, 1996; Kolk and Pinkse, 2004; McDonough and Braungart, 2002a,b).

In his influential book on Eco-Innovation, Fussler (1996) states that a majority of today's firms is not actively pursuing sustainability entrepreneurship as a strategy to create market share. However, he does not believe that this "innovation lethargy" 
(Fussler, 1996: 9) will persist in the years to come. Using a number of anecdotal case studies he shows that innovative firms can succeed in driving ecological innovation profitably, not by following current customer demand but by creating future market space. This notion that firms can actively transform market structures to make them more conducive to ecological innovation is also proposed by Dyllick (1999). Schaltegger and Wagner (2008) even propose that the ambition to transform an industry is a defining element of sustainable entrepreneurship, implying that sustainable entrepreneurial firms do not only see sustainability as central to core business activities, but at the same time aim for mass-market transformation beyond the eco-niche (Villiger et al., 2000). On the social side of sustainability entrepreneurship the term "corporate social innovation" was first introduced by Rosabeth Moss Kanter (1999: 125) who argues that firms should use social issues as a learning laboratory for identifying unmet needs and for developing solutions that create new markets. She describes, for example, BankBoston's effort in setting up a Community Bank, which has eventually evolved into a new market for the bank. More recently Patrick Cescau, CEO of Unilever, has defined corporate social innovation as a way of finding new products and services that meet not only the functional needs of consumers for tasty food or clean clothes but also their wider aspirations as citizens (cited in Webb, 2007).

An important subtheme of corporate social innovation is the focus on low-income markets. Prahalad and Hart (1999) talk in this context of the potential of the bottom or base of the pyramid (BOP) or a source for "the great leap downward" (Christensen et al., 2001: 92). The BOP premise is that by focusing on the unmet needs of low-income populations (i.e. those who are situated at the base of the wealth pyramid) firms can create profitable markets while also helping the poor address some of their most urgent needs (Christensen et al., 2001; Prahalad and Hammond, 2002; Prahalad and Hart, 2002). Prahalad's most notable assumption is that BOP markets have to pay a "poverty premium" (Prahalad and Hammond, 2002). This means that many poor have to pay more for products and services such as food, water, medication, credit, or telecommunication, than their middle or upper class compatriots. By using BOP thinking MNCs are believed to better target their design as well as improve the distribution so as to bring down the poverty premium.

In parallel to the corporate version of social entrepreneurship described above there is also a growing literature on start-up ventures motivated by social innovation. The concept of social entrepreneurship has emerged in the late 1990s (Bornstein, 1998; Boschee, 1995; Brinckerhoff, 2000; Dees, 1998a,b; Dees et al., 2001a,b; Drayton, 2002; Henton et al., 1997; Warwick, 1997). However, it has only recently reached the academic debate (Haugh, 2006; Hockerts, 2007; Light, 2006; Mair and Marti, 2006; Mair et al., 2006; Nicholls, 2006; Perrini, 2006; Robinson et al., 2009).

Ultimately, sustainable entrepreneurship is about a combination of economic, social and environmental value creation. Such integrated views of sustainable entrepreneurship are only starting to emerge in the academic literature (Cohen and Winn 2007; Dean and McMullen, 2007; Schaltegger and Wagner, 2008), which after all is the rationale for this special issue of Journal of Business Venturing.

\subsection{Firm size and the diffusion of sustainable innovation}

Whether large or small firms are more likely to pursue sustainable entrepreneurship is a question that has rarely been asked in the academic literature. In terms of entrepreneurship more broadly, however, the influence of firm size on innovation is almost a classic theme. On the one hand using economies of scale argumentation large firms have been hypothesised to be more innovative because of their broader resource base which allows them to pursue higher levels of research and development (R\&D) (e.g. Galbraith, 1956; Kamien and Schwartz, 1982; Schumpeter, 1942). In his meta-analysis of 20 studies, Damanpour (1992) finds that the positive relationship between firm size and innovation is stronger in manufacturing than service industries and relates more to innovation implementation than initiation. A contrasting, but equally popular view in the literature is that small firms are more flexible and therefore avoid some of the organizational inertia that characterizes large firms, leading to a negative correlation between firm size and innovation (Acs and Audretsch, 1987, 1988; Audretsch and Acs, 1991; Stock et al., 2002).

The innovation management literature has highlighted the particular challenges that large incumbent firms face in the light of radical innovation (Christensen, 1997; Leifer, 2000), and suggested ways to overcome those challenges such as the creation of a "radical innovation hub" (Leifer, 2001) or cooperation with outside venture capitalists (Chesbrough, 2000). Despite specific opportunities to improve innovation management in incumbent firms, Burgelman points out that there are inherent tensions in marrying large corporations with radical innovation, and that organizational attempts to overcome the challenges, such as new venture departments, will remain "a design for ambiguity" (Burgelman, 1985: 52).

One way to resolve the controversy around firm size and innovation is to move from a static to a dynamic perspective. Innovation scholars with an evolutionary economics perspective have highlighted that large and small firms play differing roles in different phases of industry evolution. As Utterback and Suarez (1993) point out, the technological trajectory of an industry is characterized by discontinuities, which lead to the emergence of a technological paradigm change (Nelson and Winter, 1982). When a new technological paradigm emerges, this results in the creative destruction (Schumpeter, 1962 [1934]) of existing competencies, thereby improving the selection environment for small entrepreneurial firms and other industry outsiders who are more flexible to pursue new opportunities without the liabilities of existing assets (Tushman and Anderson, 1986; Utterback, 1994). In terms of industry development, a technological paradigm change is usually characterized by a high degree of variation, i.e. a large number of new entrants experimenting with new product designs (Metcalfe, 1994; Utterback and Suárez, 1993). As soon as a dominant design (Utterback and Abernathy, 1975) emerges, there is a shift from variation to selection, i.e. industry consolidation and an increasing number of exits.

When it comes to the diffusion of sustainable innovation, firms are faced with additional challenges because of a double externality problem (Rennings, 2000). As in the case of conventional innovation, there is an externality in that technological spillover prevents the innovator from appropriating the full value of an innovation. In the case of sustainable innovation, however, 
there is a second externality, namely the lack of internalization of environmental or social cost for incumbent technologies. The presence of external costs has two important effects: First, it reduces the relative (private) benefit of sustainable innovation for customers. Firms who want to successfully commercialize sustainable innovation therefore need to make special efforts in convincing customers that the product they are offering is not just good for society, but also good for them. Second, the flip side of this is that government policy is playing a more important role in commercializing sustainable innovation, because it is the role of the government to internalize external cost through taxation or other economic policies. Therefore, innovating firms in the realm of sustainability need to understand government policy more so than their conventional counterparts, pointing to the importance of non-market strategies in the context of sustainable entrepreneurship.

\section{Emerging Davids, Greening Goliaths, and their interaction}

This paper conceptualises the notion that starts-ups and market incumbents each have a role to play in the transformation of industries towards sustainable development. We can observe that more and more sustainable ventures emerge as an industry is increasingly pressured to adopt sustainable development. These 'Emerging Davids' usually display a high level of environmental and/or social performance that is attractive to a select number of consumers who are very concerned about sustainability issues. However, often Davids fail to reach a broader mass market. In some cases they even have no intention to grow being content to remain in their niche.

Market incumbents on the other hand tend to focus initially on sustainability communication and accounting systems (e.g. Beske et al., 2006; Burritt and Saka, 2006; Halme and Huse, 1997; Morsing and Schultz, 2006; Seuring, 2004). While these may lead to gradual improvements, they tend to be not as efficient as hoped for (Hamschmidt and Dyllick, 2001; Schaltegger, 2002). However, faced with growing competition from 'Emerging Davids', incumbents increasingly engage in their own form of corporate sustainable entrepreneurship. These 'Greening Goliaths' promise to achieve a broader impact, since they have the potential to reach out to a mass-market audience (Villiger et al., 2000).

Extant literature on sustainable entrepreneurship has tended to cover either incumbents or new start-ups. There is very little discussion of the interplay between these two players when they engage in sustainable entrepreneurship, with the exception of a few empirical cases that are summarized in Table 3. These contributions touching upon the David/Goliath theme tend to discuss anecdotal evidence from four main substantive areas: fair trade, organic food, green electricity, and microfinance. In our subsequent theorizing we will draw on this body of literature aiming to synthesize from it a more encompassing set of insights.

\subsection{Emerging Davids: the emergence of sustainability start-ups}

New start-ups are unencumbered by the incumbents' fear of cannibalizing the market share of their prior products or devaluating previous investment in its manufacturing processes (i.e. Campion and White, 1999; Nicholls and Opal, 2005). Being

Table 3

Extant literature discussing examples of Emerging Davids and/or Greening Goliaths.

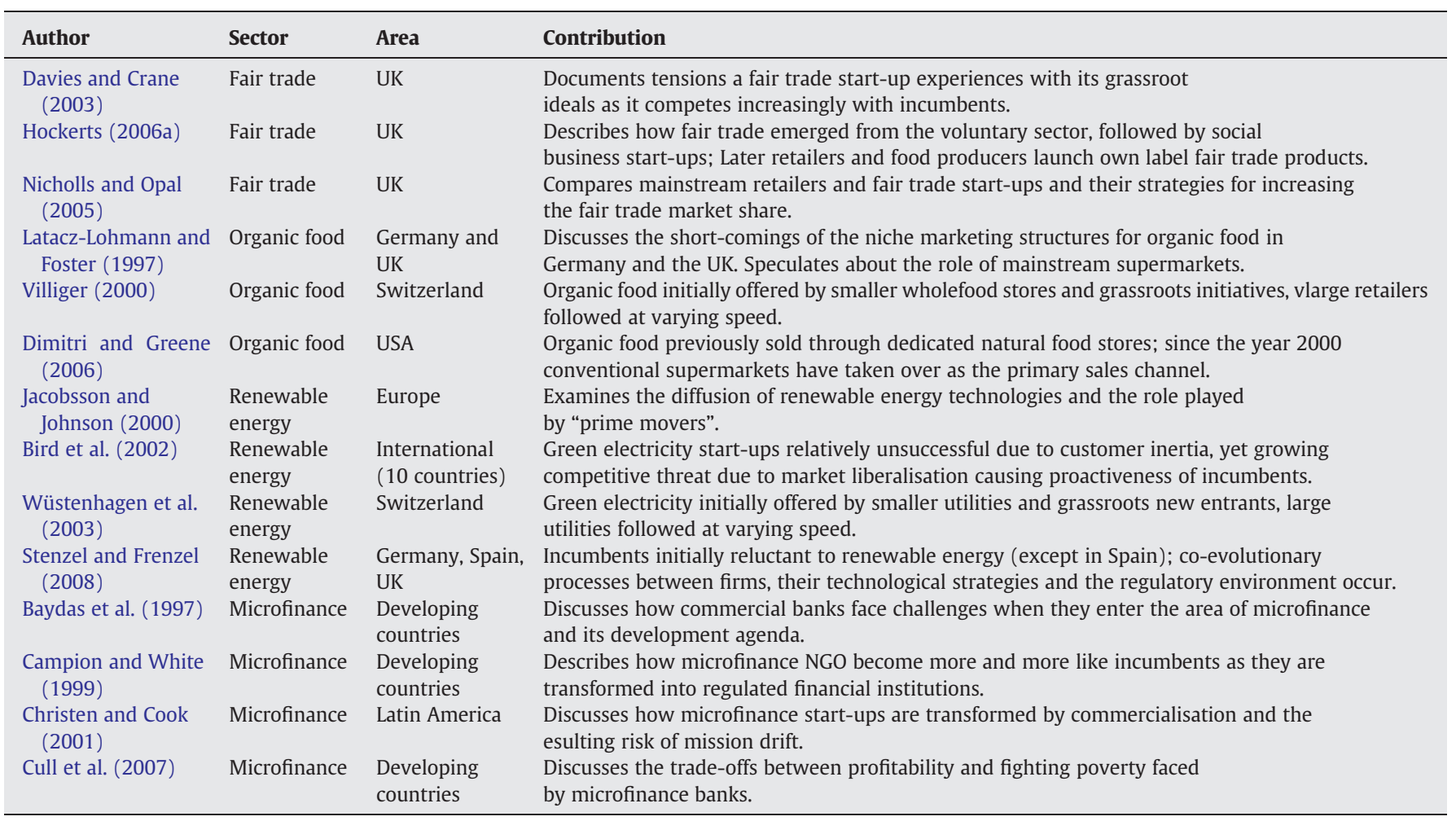


often run by idealists, sustainability start-ups are less likely to be caught in a specific technological mindset and more prone to try out innovative approaches. Furthermore, given their status as newcomers they are more credible when claiming to be part of the solution rather than the problems caused by the incumbents (Hockerts, 2006a). As a result, new start-ups are initially more likely to engage in sustainable entrepreneurship than market incumbents.

What sets sustainability start-ups apart from normal start-up companies is their pronounced value-based approach and their intention to effect social and environmental change in society. They are literally the Davids aiming to slay the giant. Realising that external costs cause environmental and social harm they make it their business to change market equilibria so as to internalize these costs and in the process to change the playing field for everybody (Cohen and Winn, 2007). They do this by asking customers to pay a premium for socially and environmentally superior products.

However, the focus on their mission also has some drawbacks. Being involved with one specific innovation, sustainability start-ups have a tendency towards single issue campaigning. They invest all their resources and attention in optimizing one particular environmental or social issue at which they try to excel. So we will, for example, find that fair trade start-ups put price premiums at the top of their sustainability agenda (Hockerts, 2006a); renewable energy producers prioritize the environmental impacts of energy production (Bird et al., 2002); and microfinance dedicated banks aim at providing loans to the poor (Christen and Cook, 2001). This might be due to the fact that their entrepreneurs are simply obsessed with one issue. It is this obsession that has often driven them to launch the business in the first place. Given their limited resources, sustainability start-ups are, however, less good at addressing a broad range of sustainability issues. The fair trade labels, for example, have been hesitant to require their suppliers to embrace environmental issues (Equal Exchange, 2002; Robins and Roberts, 1997). Similarly there is little understanding among microfinance institutions, how their loans impact the environment (Lal and Israel, 2006). And some of the entrepreneurial firms in Germany's emerging solar energy industry have faced criticism about paying low wages, which could be seen as a lack of corporate social responsibility (Williamson, 2008). There are multiple reasons for this. On the one hand start-ups lack the resources for some of the comprehensive process innovation that Goliaths tend to engage in, such as building up sustainability management systems. Moreover, they are keen to keep communications focussed on their main innovation. Finally some sustainability entrepreneurs become caught up in their own propaganda (Hockerts, 2006b).

While sustainability start-ups are keen to see their market grow, they are nonetheless often keeping that growth restricted. On the one hand there is a tendency among sustainability start-ups to keep standards undiluted and demanding. Being supported by idealistic stakeholders strongly committed to the sustainability mission, Davids are doubtful of attempts to lower standards even if this might attract more customers (e.g. Lockie, 2008). Apart from idealistic reasons to keep the market niche committed to the highest environmental or social standards, there is also an economic rationale to this. Being aware that incumbents might easily outspend them in R\&D and distribution, should they decide to enter the market niche, sustainability start-ups might prefer to keep their niche at a size that is not attracting undue interest from incumbent competitors. Over time start-ups will try to continue innovating, thus pushing up requirements for sustainability performance. As a result sustainability start-ups have an inclination to keep their niches small and exclusive.

\subsection{Greening Goliaths: the transformation of market incumbents}

In the early stages of an industry's sustainability transformation, market incumbents often react to pressure from stakeholders concerned about sustainability through incremental process innovation, e.g. by adopting sustainability communication and management systems in an attempt to better understand the issues they are facing as well as to demonstrate to stakeholders that they are sincere about their concerns. However, incumbents are also restricted by their existing assets, which reflect past investments. These often anchor incumbents in a business as usual thinking, making it less likely that they engage in sustainability entrepreneurship. This is particularly the case when sustainability-related product innovation might compete with extant products of the incumbent.

Market incumbents are initially challenged by newcomers where it concerns the primary innovation dimension of the sustainability start-up. Adapting all their product range to the highest sustainability standards is rarely an option. However, given their superior market power, financial resources and process innovation capabilities, market incumbents can play catch-up quickly once they decide to become fast followers (e.g. Dimitri and Greene, 2006; Hockerts, 2006a). Incumbents may, for example, find it opportune to launch copy-cat products that resemble those of the start-ups in order to reap part of the premiums that dedicated consumers are willing to pay. All major electricity utilities have, for example, launched some kind of tariff that promises their clients electricity from environmentally preferable sources (Bird et al., 2002; Delmas et al., 2007). Incumbents may also decide to launch corporate venture capital (CVC) funds to keep an eye on innovating Davids (Teppo and Wüstenhagen, 2010). This provides them with an option to integrate sustainability innovation when it turns out to be disruptive.

While market incumbents tend to lag behind start-ups concerning the primary sustainability innovation, their strength lies in process innovation. For example, they have a tendency to invest in more encompassing sustainability management systems (Hamschmidt and Dyllick, 2001). Thus they will be addressing multiple environmental and social issues where sustainability startups focus on one or two issues only. Employing tools such as environmental and social management and reporting systems, market incumbents will find it easier to develop a broad sustainability performance.

In some cases market incumbents may be interested in less ambitious sustainability standards compared to sustainability startups. As an example, in the debate about Switzerland's "agricultural policy 2002" in the early 1990s, the country's leading retailer Migros actively lobbied for Integrated Pest Management (IP) rather than the stricter guidelines of organic agriculture as the 
standard that would be the base for environmental subsidies to farmers (Villiger, 2000). However, Goliaths are if anything even more interested than Davids in codifying these standards explicitly since they lack the reputation for environmental or social leadership that some sustainability start-ups have (Giovannucci and Ponte, 2005; Truffer et al., 2001). The existence of a broadly accepted product standard or label creates a level playing field between incumbents and start-ups. Research indicates that such standards are not contributing much to the overall performance (Seuring and Müller, 2008). They rather form a minimum requirement that has to be met in order to avoid related problems. Incumbents will tend to attempt to keep standards fixed rather than encouraging continued innovation. The embrace of the Rainforest Alliance label by multinational Kraft can be seen as an example of a multinational trying to enter the fair trade niche without having to be subject to the stricter requirements (i.e. minimum price, price premiums, pre-financing, long-term contracts) of the Fair Trade Labelling Organisation (FLO) (McAllister, 2004).

\subsection{Co-evolution of Davids and Goliaths}

Both Davids and Goliaths have a role to play in the sustainability transformation of an industry. In fact the interaction between the two resembles a co-evolution, whereby each side moves the transformation further. Co-evolution is a term from biology describing the simultaneous evolution of species who mutually depend on each other (Ehrlich and Raven, 1964). The term has been used to describe the interaction of natural and social systems by ecological economists such as Norgaard (1994). One can distinguish several phases of transformation (see Fig. 2). In a first stage sustainability start-ups launch the sustainability innovation to the market. Often these start-ups are run by highly motivated idealists who work in close cooperation with NGOs and charities (Hockerts, 2006a; Meijkamp, 2000). Being placed in-between the third sector and the formal economy these alternative players do have profit motives although they are usually more driven by a desire to achieve environmental and social change. In his typology of ecopreneurs, linking the terms 'bio' and 'pioneer', Schaltegger (2002) calls these actors 'bioneers', while Zahra et al. (2009) refer to them as 'social bricoleurs' in the context of social entrepreneurship. Often these bioneers/bricoleurs never grow beyond a small niche thus actually not affecting disruptive change. However, in a few cases they can change into sustainable entrepreneurs. Both the organic food and the fair trade markets, for example, have seen many specialised producers (e.g. Demeter, CaféDirect) and retailers (e.g. One World Shops; Organic food shops) pop up in the early days of the movement (Dimitri and Greene, 2006; Hockerts, 2006a). Similarly, local grassroots initiatives engaged in producing their own solar collectors decades before the word cleantech became fashionable in Silicon Valley (Wüstenhagen, 2000), and idealist bricoleurs preceded the current quest for lighter, more efficient cars by a long time (Truffer and Dürrenberger, 1997).

While bioneers or social bricoleurs kick off sustainability transformation, they are usually followed quite quickly by some market incumbents once early growth picks up. These would usually be leading premium brands who offer line extensions to capitalise on the growing trend. Since the late 1990s, food producers and retailers have discovered the organic and fair trade niches for themselves (Villiger, 2000). Around the same time, incumbent electric utilities started experimenting with green electricity offerings (Bird et al.,

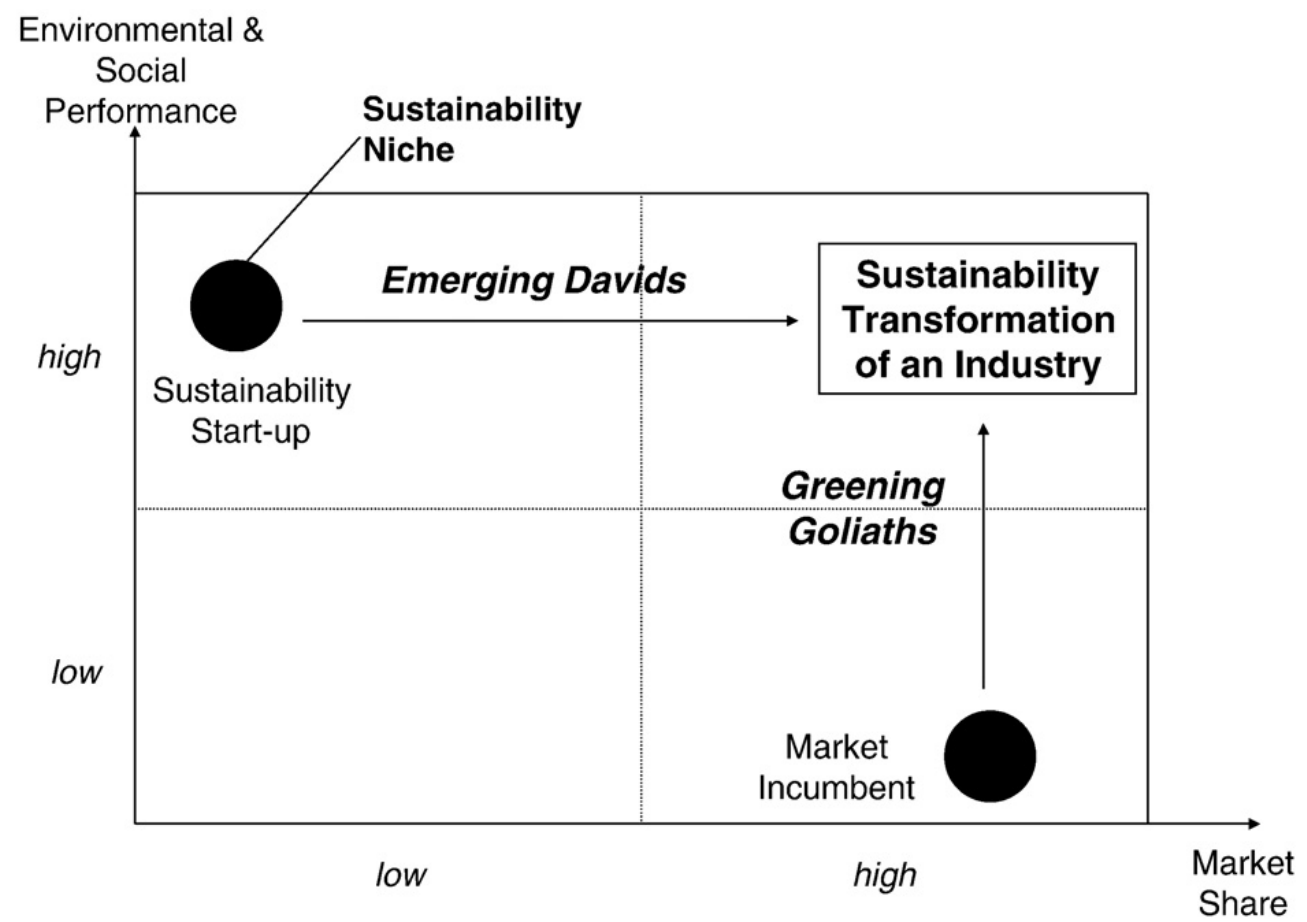

Fig. 2. Co-evolution of sustainability start-ups and market incumbents towards the sustainability transformation of an industry. 
2002), and car manufacturers have launched cleaner cars (Canzler and Knie, 1995). Their offers usually make up only small line extensions. Retailers such as for example Sainsbury's and the Co-op have been early adopters of both organic and fair trade products.

As the sustainability transformation of a market continues, a different type of sustainability start-up company begins to emerge. The high-growth Davids in this third phase are much more business-like and often backed by more professional investors. They combine the best of both worlds by orchestrating the product innovation of the early Davids with the process innovation that Goliaths are typically good at. Having observed the development of the bioneers they have a good understanding of the market niche and now aim to extend it through more professional management. These start-up firms do not share the implicit motto of many bioneers that to stay 'small is beautiful' (Schumacher, 1974). Instead they have also a clearer expectation to achieve profitable growth and to extend market share, while defending it against incumbents. Examples for these types of start-ups include the organic retailer WholeFoods market in the U.S., the British Fair Trade Brand CaféDirect (Hockerts, 2006a), green power marketers such as Green Mountain Energy in the US and Lichtblick in Germany (Wüstenhagen, 2000), and solar cell producers such as Q-Cells or Solarworld in Germany (Schönwandt, 2004).

The final and fourth stage of maturity of sustainability entrepreneurship tends to extend to the mass-market brands that begin to see both a growing competitive threat from the start-ups and a market potential for themselves. Typical examples for this include WalMart's decision to enter the organic market (Gunther, 2006; Warner, 2006), Kraft's adoption of the Rainforest Alliance Label (McAllister, 2004) and the decision of energy incumbent Siemens to follow the lead of their competitor GE and enter the growing wind turbine manufacturing business in 2004 (Lewis and Wiser, 2007). Being more cost driven than premium incumbents, these late entrants into the sustainability niche often bring process innovation along the supply chain to the table. WalMart, for example, explicitly aims to bring down the cost of organic food so that it no longer remains just a luxury item for the upper middle classes but also becomes accessible for typical WalMart clients (Gunther, 2006). On one hand, this clearly contributes positively to the sustainability transformation of an industry, because it improves access to products of higher social and environmental quality to a wider part of the market, and is likely to reduce other sustainability impacts through process innovation along the way. On the other hand, the entrance of cost-conscious Goliaths increases the pressure to somewhat lower sustainability criteria and to give up some of the ideals cherished by the first generation bioneers (Lockie, 2008). The Fair Trade Labelling Organization (FLO), for example, has begun to relax some of its standards in response to the pressure from competing schemes such as the Rainforest Alliance label. So to some extent, the price of gaining more breadth may be to lose depth in terms of sustainability quality. At this stage of development, then, we can expect the re-emergence of Davids to create new high-end market niches, eventually starting the transformation cycle over again. A typical example is Swiss entrepreneur Nicolas Hayek who, more than a decade after exiting from a joint venture with Daimler that aimed at revolutionalizing personal mobility but then resulted in the fairly traditional Smart car, has set up Belenos Clean Power, a new firm to pursue the commercialization of hydrogen-powered electric vehicles.

\section{Conclusions}

Sustainable entrepreneurship research so far has neglected the differential roles of large and small firms in transforming industries towards sustainable development. The theme has not been adequately addressed in the corporate sustainability literature either. While sustainable entrepreneurship scholars tend to focus predominantly on the role of start-ups, corporate sustainability scholars tend to focus their attention towards what happens in large firms. This article has aimed at advancing the academic discussion on sustainable entrepreneurship by (i) highlighting the differential roles of "Davids" and "Goliaths" in the sustainable transformation of industries, (ii) discussing the specific opportunities and challenges of "Emerging Davids" and "Greening Goliaths" as pathways towards sustainable development, and (iii) exploring the interaction of entrepreneurial initiatives in small and large companies in bringing about this development. Our analysis has resulted in a dynamic view of industry transformation, where the initial phase is characterized by sustainability initiatives of idealistic "Davids". In a second phase, some pioneering "Goliaths", for example retailers with a higher quality positioning, mimic some of the David initiatives and try to bring them into their mainstream distribution channels. In isolation, none of these two developments would necessarily lead to sustainable transformation of mainstream markets, because as we have argued above Davids tend to get stuck in their highquality, low-market penetration niche, while Goliaths have an inherent tendency to react to cost pressures by lowering the sustainability quality of their offerings. However, we see increasing evidence for a next stage of development on both paths. As for "Emerging Davids", firms such as Wholefoods, Green Mountain Energy, Vestas or Ben\&Jerry's have found ways to scale up their sustainable innovations without unduly compromising on their sustainability ambitions. On the other hand, in the "Greening Goliaths" camp, there are examples of large firms such as Walmart, GE, Kraft or Toyota who have taken on the challenge of building sustainability into their mainstream business. Arguably, the success of emerging Davids, which can also be seen as a potential competitive threat, has been instrumental for some of these Goliaths to embark on the level of sustainable entrepreneurship that they did. Therefore, we would argue that the sustainable transformation of industries is not going to be brought about by either Davids or Goliaths alone, but instead that their interaction is essential.

Our conceptual model points to interesting avenues for further research. It has been suggested that social entrepreneurship research should move beyond the single case study designs in the early days of the discipline and towards larger samples (Hockerts, 2006b). This is certainly true for sustainable entrepreneurship research as well, but we would suggest that additional insights can be gained from comparative studies of sustainable entrepreneurial initiatives in both small and large firms. In such studies, it would be particularly interesting to watch out for the specific challenges encountered by "Davids" and "Goliaths" in their attempts to broaden and deepen the level of their impact. This could be done retrospectively by doing in-depth case studies on 
some of the cases of successful "Emerging Davids" and "Greening Goliaths" mentioned above. Even more insightful would be longitudinal case studies of a set of small and large companies moving towards sustainability, whereby the focus could be on either market or non-market strategies of Davids and Goliaths. There is also scope for empirically testing our model in other industries such as the water sector or the greening of information technology (IT) services. A further area of interest would be to specifically investigate arenas where Davids and Goliaths interact. Looking at external corporate venturing programs in sustainability-related industries such as energy, water or transportation might be a good focus for that. Further research could also take an investor perspective and ask for the optimal portfolio allocation between Davids and Goliaths for simultaneously achieving high economic, social and environmental performance. Finally, an important fundamental research question is whether there are indeed successful examples of the sustainability transformation of industries, i.e. the move towards the upper right corner of Fig. 2. While we see evidence that the interaction of Davids and Goliaths does make a positive contribution towards this objective, we have also listed numerous limitations and challenges that each Davids and Goliaths are facing on their respective transformation paths. Against the background of some of the sobering trends in global environmental and social impacts (WWF, 2006), it is worth critically examining - albeit well beyond the scope of this paper - whether the final outcome of this co-evolution is indeed in line with the requirements of sustainable development.

Our model has important policy implications. The findings discussed in this paper suggest that what is needed could be referred to as an ambidextrous innovation policy for sustainability. O'Reilly and Tushman (2004) refer to ambidextrous organizations as those that master the art of simultaneously pursuing incremental and disruptive innovation. Similarly, achieving the sustainable transformation of an industry requires a finetuned mix of disruptive and incremental innovation, which can be promoted if policymakers understand the nuanced interplay of Emerging Davids and Greening Goliaths, rather than single-mindedly focusing on only one of these paths while neglecting the other. Arguably, policymakers have a tendency to favour incumbents over entrepreneurial start-ups, so designing sustainability policies with an entrepreneurial perspective in mind is a good start, but this paper would suggest that smart innovation policies should try to leverage cooperation and competition between Davids and Goliaths.

\section{References}

Acs, Z.J., Audretsch, D.B., 1987. Innovation, market structure, and firm size. The Review of Economics and Statistics 567-574.

Acs, Z.J., Audretsch, D.B., 1988. Innovation in large and small firms: an empirical analysis. The American Economic Review 678-690.

Audretsch, D.B., Acs, Z.J., 1991. Innovation and size at the firm level. Southern Economic Journal 739-744.

Baron, D., 1995. Integrated strategy: market and nonmarket components. California Management Review 37 (2), $47-65$.

Baydas, M.M., Graham, D.H., Valenzuela, L., 1997. Commercial Banks in Microfinance: New Actors in the Microfinance World. Microenterprise Best Practices.

Beske, P., Koplin, J., Seuring, S., 2006. The use of environmental and social standards by German first-tier suppliers of the Volkswagen AG. Corporate Social Responsibility and Environmental Management.

Bird, L.A., Wüstenhagen, R., Aabakken, J., 2002. A review of international green power markets: recent experience, trends, and market drivers. Renewable and Sustainable Energy Reviews 6 (6), 513-536.

Boehnke, J., Wüstenhagen, R., 2007. Business models for distributed energy technologies - evidence from German cleantech firms. Academy of Management Conference, Philadelphia. August 2007.

Bornstein, D., 1998. Changing the world on a shoestring. The Atlantic Monthly 281 (1), 34-39.

Boschee, J., 1995. Social entrepreneurship. Across the Board 32 (3), 20-24.

Braungart, M., McDonough, W., 1998. The next industrial revolution. The Atlantic Monthly 82-92 1998(Oct).

Brinckerhoff, P.C., 2000. Social Entrepreneurship: The Art of Mission-Based Venture Development. John Wiley \& Sons, New York.

Brundtland Commission, 1987. Our Common Future. World Commission on Environment and Development, Brussels.

Burgelman, R.A., 1985. Managing the new venture division: research findings and implications for strategic management. Strategic Management Journal 6 (1).

Burritt, R., Saka, C., 2006. Environmental management accounting applications and eco-efficiency: case studies from Japan. Journal of Cleaner Production 14 (14), $1262-1275$.

Campion, A., White, V., 1999. Institutional Metamorphosis: Transformation of Microfinance NGOs Into Regulated Financial Institutions. MicroFinance Network. Canzler, W., Knie, A., 1995. Über eine Idee wächst Gras, Die Zeit, Vol. 13/1995: 51.

Chesbrough, H., 2000. Designing corporate ventures in the shadow of private venture capital. California Management Review 42 (3), $31-49$.

Christen, R. \& Cook, T. 2001. Commercialization and Mission Drift: The Transformation of Microfinance in Latin America: CGAP.

Christensen, C.M., 1997. The Innovators Dilemma, When New Technologies Cause Great Firms to Fail. Harvard Business Press, Boston.

Christensen, C.M., Craig, T., Hart, S.L., 2001. The Great Disruption. Foreign Affairs 80 (2), 80-95.

Cohen, B., Winn, M.I., 2007. Market imperfections, opportunity and sustainable entrepreneurship. Journal of Business Venturing 22 (1), 29-49.

Cull, R., Demirguc-Kunt, A., Morduch, J., 2007. Financial performance and outreach: a global analysis of leading microbanks*. The Economic Journal 117 (517), F107-F133.

Daly, H.E., 1973. Towards a Steady State Economy. Freeman, San Francisco.

Daly, H.E., 1991. Steady-State Economics, 2nd ed. Island Press, Washington, D.C.

Damanpour, F., 1992. Organizational size and innovation. Organization Studies 13 (3), 375.

Davies, I.A., Crane, A., 2003. Ethical decision making in fair trade companies. Journal of Business Ethics 45 (1), 79-92.

Dean, T.J., McMullen, J.S., 2007. Toward a theory of sustainable entrepreneurship: reducing environmental degradation through entrepreneurial action. Journal of Business Venturing $22(1), 50-76$.

Dees, J.G., 1998a. Enterprising nonprofits. Harvard Business Review 76 (1), 54-66.

Dees, J.G.; The Meaning of Social Entrepreneurship; 31 October 1998.

Dees, J.G., Emerson, J., Economy, P., 2001a. Strategic Tools for Social Entrepreneurs: Enhancing the Performance of Your Enterprising Nonprofit. John Wiley \& Sons, New York.

Dees, J.G., Emerson, J., Economy, P., 2001b. Enterprising Nonprofits: A Toolkit for Social Entrepreneurs. John Wiley \& Sons, New York.

Delmas, M., Russo, M.V., Montes-Sancho, M.J., 2007. Deregulation and environmental differentiation in the electric utility industry. Strategic Management Journal 28 (2), 189-209.

Dimitri, C., Greene, C., 2006. Recent growth patterns in the US organic foods market. Organic Agriculture in the US, p. 129.

Drayton, W., 2002. The citizen sector: becoming as entrepreneurial and competitive as business. California Management Review 44 (3), $120-132$.

Dyllick, T., 1999. Environment and competitiveness of companies. In: Hitchens, D., Clausen, J., Fichter, K. (Eds.), International Environmental Management Benchmarks. Springer, Berlin.

Dyllick, T., Hockerts, K., 2002. Beyond the business case for corporate sustainability. Business Strategy and the Environment 11 (2), $130-141$.

Dyllick, T., Belz, F., Schneidewind, U., 1997. Ökologie und Wettbewerbsfähigkeit. Hanser, Munich. 
Eckhard, J., Shane, S.A., 2003. The importance of opportunities to entrepreneurship. Journal of Management 29 (3), 333-349.

Ehrlich, P.R., Raven, P.H., 1964. Butterflies and plants: a study of coevolution. Evolution 18, 586-608.

Elkington, J., 1997. Cannibals With Forks: The Triple Bottom Line of 21st Century Business. Capstone, Oxford.

Equal Exchange; Are All Fair Trade Products Organic?; http://www.equalexchange.co.uk/FAQ.htm; 8 September 2002.

Fussler, C., 1996. Driving Eco-innovation, A Breakthrough Discipline for Innovation and Sustainability. Pitman, London.

Galbraith, J.K., 1956. American Capitalism: The Concept of Countervailing Power. Hougton Mifflin, Boston.

Giovannucci, D., Ponte, S., 2005. Standards as a new form of social contract? Sustainability initiatives in the coffee industry. Food Policy 30 (3), $284-301$.

Gunther, M., 2006. The green machine. Fortune Magazine, pp. 42-46. 7 Aug 2006.

Halme, M., Huse, M., 1997. The influence of corporate governance, industry and country factors on environmental reporting. Scandinavian Journal of Management 13 (2), 137-157.

Hamschmidt, J., Dyllick, T., 2001. ISO 14001: Profitable? Yes! But is it eco-effective? Greener Management International 34, 43-54.

Hart, S.L., Milstein, M.B., 1999. Global sustainability and the creative destruction of industries. Sloan Management Review 41 (1), $23-33$.

Hart, S.L., Milstein, M.B., 2003. Creating sustainable value. Academy of Management Executive 17 (2), 56-67.

Haugh, H., 2006. Social enterprise: beyond economic outcomes and individual returns. In: Mair, J., Robinson, J., Hockerts, K.N. (Eds.), Social Entrepreneurship. Palgrave MacMillan, New York.

Henton, D., Melville, J., Walesh, K., 1997. Grassroots leaders for a new economy: how civic entrepreneurs are building prosperous communities. National Civic Review 86 (2), 149-156.

Hillman, A., Hitt, M., 1999. Corporate political strategy formation: a model of approach, participation and strategy decisions. Academy of Management Review 24, $825-842$.

Hockerts, K., 1999. The sustainability radar - a tool for the innovation of sustainable products and services. Greener Management International 1999 (25), 29-49.

Hockerts, K. 2003. Sustainability innovations, ecological and social entrepreneurship and the management of antagonistic assets. Ph.D. Thesis, University St. Gallen, Bamberg: Difo-Druck.

Hockerts, K., 2006a. CaféDirect: a social entrepreneurial fair trade success. In: Perrini, F. (Ed.), The New Social Entrepreneurship, What Awaits Social Entrepreneurial Ventures. Edward Elgar.

Hockerts, K., 2006b. Entrepreneurial opportunity in social purpose business ventures. In: Mair, J., Robertson, J., Hockerts, K.N. (Eds.), Social Entrepreneurship, vol. 1. Palgrave MacMillan.

Hockerts, K., 2007. Social Entrepreneurship. In: Visser, W., Matten, D., Pohl, M., Tolhurst, N. (Eds.), The A to Z of Corporate Social Responsibility: A Complete Guide to Concepts, Codes and Organisations: 422. John Wiley, Hoboken.

Jacobsson, S., Johnson, A., 2000. The diffusion of renewable energy technology: an analytical framework and key issues for research. Energy Policy 28 (9), 625-640.

Kamien, M.I., Schwartz, N.L., 1982. Market Structure and Innovation. Cambridge University Press.

Kanter, R.M., 1999. From spare change to real change: the social sector as a beta site for business innovation. Harvard Business Review 77 (3), $123-132$.

Keating, M., 1993. The Earth Summit's Agenda for Change. Centre for Our Common Future, Geneva.

Ki-moon, B., Gore, A., 2009. Green growth is essential to any stimulus. Financial Times 917 February 2009.

Kolk, A., Pinkse, J., 2004. Market strategies for climate change. European Management Journal 22 (3), 304-314.

Lal, A., Israel, E., 2006. An overview of microfinance and the environmental sustainability of smallholder agriculture. International Journal of Agricultural Resources, Governance and Ecology 5 (4), 356-376.

Latacz-Lohmann, U., Foster, C., 1997. From“ niche” to “ mainstream”-strategies for marketing organic food in Germany and the UK. British Food Journal 99 (8), 275-282.

Leifer, R., 2000. Radical Innovation: How Mature Companies Can Outsmart Upstarts. Harvard Business School Press.

Leifer, R., 2001. Implementing radical innovation in mature firms: the role of hubs. The Academy of Management Executive (1993-2005) 102-113.

Lewis, J.I., Wiser, R.H., 2007. Fostering a renewable energy technology industry: an international comparison of wind industry policy support mechanisms. Energy Policy 35 (3), 1844-1857.

Light, P., 2006. Searching for social entrepreneurs: who they might be, where they might be found, what they do. Research on Social Entrepreneurship: Understanding and Contributing to an Emerging Field.

Lockie, S., 2008. Conversion or co-option? The implications of 'mainstreaming' for producer and consumer agency within fair trade networks. Creating Food Futures: Trade, Ethics and the Environment 215.

Lovins, A.B., Lovins, L.H., Hawken, P., 1999. Natural Capitalism: Creating the Next Industrial Revolution. Little Brown.

Mair, J., Marti, I., 2006. Social entrepreneurship research: a source of explanation, prediction, and delight. Journal of World Business 41 (1), 36-44.

Mair, J., Robinson, J., Hockerts, K. (Eds.), 2006. Social Entrepreneurship, vol. 1. Palgrave MacMillan, New York.

McAllister, S., 2004. Who is the fairest of them all? The Guardian 24.

McDonough, W., Braungart, M., 2002a. Cradle to cradle: remaking the way we make things. North Point Press, New York.

McDonough, W., Braungart, M., 2002b. Design for the triple top line: new tools for sustainable commerce. Corporate Environmental Strategy 9 (3), $251-258$.

Meadows, D.L., 1977. Alternatives to growth - in search for sustainable futures. Paper presented at the Proceedings of the 1975 Alternatives to Growth Conference, Woodlands, TX.

Meadows, D., Meadows, D.L., Randers, J., Behrens, W., 1971. The Limits to Growth. Universe Books, New York.

Meadows, D.L., Meadows, D., Randers, J., 1991. Beyond the Limits. Chelsea Green Publishing, Post Mills.

Meijkamp, R.G. 2000. Changing Consumer Needs by Eco-efficient services: An empirical study on car-sharing. Unpublished PhD Thesis, DfS Publication No. 3, Delft University of Technology, Delft.

Metcalfe, J.S., 1994. Evolutionary economics and technology policy. The Economic Journal 931-944.

Morsing, M., Schultz, M., 2006. Corporate social responsibility communication: stakeholder information, response and involvement strategies. Business Ethics: A European Review 15 (4), 323-338.

Nelson, R.R., Winter, S.G., 1982. An Evolutionary Theory of Economic Change. Belknap Press of Harvard University Press.

Nicholls, A., 2006. Social Entrepreneurship: New Models of Sustainable Social Change. Oxford University Press, USA.

Nicholls, A., Opal, C., 2005. Fair Trade: Market-Driven Ethical Consumption. Sage.

Norgaard, R.B., 1994. Development betrayed: the end of progress and a coevolutionary revisioning of the future. Routledge, London, New York.

O'Reilly, C.A.I., Tushman, M., 2004. The Ambidextrous Organization. Harvard Business Review 74-81 (April).

Parker, N., O'Rourke, A., 2006. The Cleantech Venture Capital Report-2006. Cleantech Venture Network LLC.

Perrini, F., 2006. The New Social Entrepreneurship, What Awaits Social Entrepreneurial Ventures. Edward Elgar.

Prahalad, C.K., Hart, S.L., 1999. Strategies for the Bottom of the Pyramid: Creating Sustainable Development.

Prahalad, C.K., Hammond, A., 2002. Serving the world's poor, profitably. Harvard Business Review 80 (9), $48-57$.

Prahalad, C.K., Hart, S.L., 2002. The fortune at the bottom of the pyramid. Business and Strategy (1st Quarter) 26, 2-14.

Rennings, K., 2000. Redefining innovation - eco-innovation research and the contribution from ecological economics. Ecological Economics 32 (2), 319-332.

Robins, N., Roberts, S., 1997. Reaping the benefits: trade opportunities for developing producers from sustainable consumption and production. Greener Management International Autumn 1997 (19), 53-67.

Robinson, J., Mair, J., Hockerts, K (Eds.), 2009. International Perspectives on Social Entrepreneurship, vol. 1. Palgrave MacMillan, New York.

Russo, M.V., 2003. The emergence of sustainable industries: building on natural capital. Strategic Management Journal 317-331.

Schaltegger, S., 2002. A framework for ecopreneurship: leading bioneers and environmental managers to ecopreneurship. Greener Management International $2002(38), 45-58$

Schaltegger, S., Wagner, M., 2008. Types of sustainable entrepreneurship and conditions sustainability innovation: from administration of a technical challenge to the management entrepreneurial opportunity. In: Wüstenhagen, R., Hamschmidt, J., Sharma, S., Starik, M. (Eds.), Sustainable Innovation and Entrepreneurship. Edward Elgar, Cheltenham, UK. 
Schumacher, E.F., 1974. Small is Beautiful. Abacus, London.

Schumpeter, J.A., 1942. Capitalism, Socialism and Democracy. Harper and Brothers.

Schumpeter, J.A., 1962 [1934]]. The Theory of Economic Development. Oxford University Press, New York.

Schönwandt, C., 2004. Sustainable Entrepreneurship im Sektor erneuerbare Energien. Hampp.

Senge, P., Carstedt, G., 2001. Innovating our way to the next industrial revolution. Sloan Management Review 42 (2), $24-39$.

Seuring, S., 2004. Industrial ecology, life cycles, supply chains: differences and interrelations. Business Strategy and the Environment 13 (5), $306-319$.

Seuring, S., Müller, M., 2008. From a literature review to a conceptual framework for sustainable supply chain management. Journal of Cleaner Production 16 (1699-1710).

Shane, S., Venkataraman, S., 2000. The promise of entrepreneurship as a field of research. Academy of Management Review 25 (1), $217-227$.

Siebenhüner, B., Dedeurwaerdere, T., Brousseau, E., 2005. Introduction and overview to the special issue on biodiversity conservation, access and benefit-sharing and traditional knowledge. Ecological Economics 53 (4), 439-444.

Stenzel, T., Frenzel, A., 2008. Regulating technological change. The strategic reactions of utility companies towards subsidy policies in the German, Spanish and UK electricity markets. Energy Policy 36, 2645-2657.

Stivers, R., 1976. The Sustainable Society: Ethics and Economic Growth. Westminster Press, Philadelphia.

Stock, G.N., Greis, N.P., Fischer, W.A., 2002. Firm size and dynamic technological innovation. Technovation 22 (9), $537-549$.

Teppo, T., Wüstenhagen, R., 2010. Why Corporate Venture Capital Funds Fail - evidence from the European Energy Industry. International Journal of Entrepreneurship and Innovation Management 5 (4), 353-375.

Truffer, B., Dürrenberger, G., 1997. Outsider initiatives in the reconstruction of the car: the case of light weight vehicle milieus in Switzerland. Science, Technology, \& Human Values 22 (2), 207-234.

Truffer, B., Markard, J., Wüstenhagen, R., 2001. Eco-labeling of electricity-strategies and tradeoffs in the definition of environmental standards. Energy Policy 29 (11), 885-897.

Tushman, M.L., Anderson, P., 1986. Technological discontinuities and organizational environments. Administrative Science Quarterly 31, 439-465.

Utterback, J.M., 1994. Mastering the dynamics of innovation. How companies can seize opportunities in the face of technological change. Harvard Business School Press, Boston/MA.

Utterback, J.M., Abernathy, W.J., 1975. A dynamic model of product and process innovation. Omega 3 (6), 639-656.

Utterback, J.M., Suárez, F.F., 1993. Innovation, competition, and industry structure. Research Policy 22, 1-21.

Villiger, A., 2000. Von der Nische zum Massenmarkt, Strategien und Perspektiven für den Lebensmittelsektor. Deutscher Universitäts-Verlag, Wiesbaden.

Villiger, A., Wüstenhagen, R., Meyer, A., 2000. Jenseits der Öko-Nische. Birkhäuser, Basel.

Warner, M., 2006. Wal-Mart eyes organic foods. New York Times. 12 May 2006.

Warwick, D., 1997. Will social entrepreneurs blossom or hit bottom? People Management 3 (20), 56.

Waters, R., 2008. Silicon Valley warns Detroit rescue could pull the plug on electric cars. Financial Times 158 Dec 2008.

Webb, T. 2007. Strategy \& Management: Unilever's CEO: Social innovation and sustainability the only game in town. Ethical Corporation, No. 5 (2007).

Williamson, H., 2008. Not everyone happy in Germany's Solar Valley. Financial Times 11 March 2008.

WWF, 2006. Living planet report 2006. Gland, Switzerland WWF.

Wüstenhagen, R., 1998. Greening Goliaths vs. Multiplying Davids, Pfade einer Coevolution ökologischer Massenmärkte und nachhaltiger Nischen. IWÖ-HSG, St. Gallen.

Wüstenhagen, R., 2000. Ökostrom - Von der Nische zum Massenmarkt, Entwicklungsperspektiven und Marketingstrategien für eine zukunftsfähige Elektrizitätsbranche. vdf, Zürich.

Wüstenhagen, R., Markard, J., Truffer, B., 2003. Diffusion of green power products in Switzerland. Energy Policy 31 (621-632).

Wüstenhagen, R., Hamschmidt, J., Sharma, S., Starik, M. (Eds.), 2008. Sustainable Innovation and Entrepreneurship. Edward Elgar, Cheltenham, UK • Northampton, MA, USA.

Zahra, S.A., Gedajlovic, E., Neubaum, D.O., Shulman, J.M., 2009. A typology of social entrepreneurs: Motives, search processes and ethical challenges. Journal of Business Venturing 24 (5), 519-532. 